\title{
Tracing the linguistic crossroads between Malay and Tamil
}

\author{
TOM G. HOOGERVORST \\ Coretan ini cuma salah satu dari hasil karya yang terlahir \\ dari kemurahan hati dan dorongan yang berterusan \\ dari Pak Hein.
}

\begin{abstract} Malay and Tamil varieties.

KEYWORDS

Malay, Tamil, language contact, loanwords.
\end{abstract}

Speakers of Malay and Tamil have been in intermittent contact for roughly two millennia, yet extant academic work on the resultant processes of contact, lexical borrowing, and language mixing at the interface of these two speech communities has only exposed the tip of the proverbial iceberg. This paper presents an historical overview of language contact between Malay and Tamil through time and across the Bay of Bengal. It concludes with a call for future studies on the lexicology, dialectology, and use of colloquial language of both

\section{INTRODUCTION}

When Europeans first entered the waters of the Indian Ocean, they encountered a vibrant, interconnected world in which Gujaratis, Persians, Tamils, Swahilis, Arabs, Malays, and a wide range of other peoples traded and settled on shores other than their own. Upon arriving in Malacca in the 1510s, the Portuguese apothecary Tomé Pires noted no less than 61 different nations inhabiting that city, representing much of the Asian continent and the Indian Ocean World. Facilitated by the annual cycle of the monsoon, the Malay-speaking settlements on both sides of the Strait of Malacca formed vital trade entrepôts connecting various parts of Asia and facilitating the dispersal of people, products and ideas. Language contact must have been pervasive in the Malay speech area

TOM G. HOOGERVORST took his PhD degree at the University of Oxford as part of a project on cultural contact in the pre-modern Indian Ocean World. He is currently a postdoctoral researcher at the Royal Netherlands Institute of Southeast Asian and Caribbean Studies (KITLV). His main research interest is in the Malay language and linguistic history. In this field of inquiry, his former teacher Hein Steinhauer has been and continues to be an inspiration. Tom G. Hoogervorst may be contacted at: hoogervorst@kitlv.nl.

(c) 2015 Faculty of Humanities, University of Indonesia 
since time immemorial. However, while the lexical influence from high-status literary languages such as Sanskrit and Arabic on Malay is relatively wellknown (Jones 2007), the impact of spoken vernaculars remains much less so. This is due in part to the fact that many vernacular languages of South and Southeast Asia are themselves understudied, especially in language ecologies characterized by wide-ranging diglossia. Furthermore, language contact between Southeast Asia and other regions of Asia has long been approached as a unidirectional process, reducing Southeast Asia's populations to mere recipients. There is a modicum of work on the dispersal of pre-modern loanwords from West-Malayo-Polynesian languages to other languages of the Indian Ocean (Hoogervorst 2013), but more could be done in this area. With the exception of Sri Lanka Malay, mixed languages at the interface of Malay and Tamil are almost undocumented.

An historical analysis of language contact between Malay and Tamil, as will be attempted here, provides a better understanding of the past of the Bay of Bengal as an axis of global trade and cultural exchange. This study traces the shared history of two of the largest speech communities of the Indian Ocean World, reconstructing their inter-relationship across several time periods and geographical settings. In the absence of accurate grammatical descriptions of most of the "hybrid" linguistic varieties discussed in this paper, much of my analysis will be of etymological nature. Consequently, this paper cannot be anything but sweeping and remains far from exhaustive. Most of the data and insights presented here are taken from secondary sources, rather than first-hand fieldwork. That being said, the paucity and scattered distribution of scholarship on Malay-Tamil language contact calls for a synthesis and overview of the available data as a first step to determine pathways for further research. In doing so, this study serves to demonstrate what we know, but also what we do not know. It is structured as follows: Section 2 summarizes the long history of contact between Malay and Tamil; Section 3 focuses on relationship between the two languages as reflected in the classical Malay literature; Section 4 introduces the type of Malay spoken by Tamils at present; Section 5 surveys Malay varieties in historical contact with Tamil; Section 6 traces the languages spoken by mixed Malay-Tamil communities; and Section 7 synthesizes our present state of knowledge on the Tamil variety (or varieties) used in Malaysia.

\section{HISTORY OF CONTACT}

The archaeological record reveals that contact between South India and Southeast Asia was regular from the first centuries BCE (Ardika and Bellwood 1991; Bellina and Glover 2004). The Old Javanese kakawin literature contains numerous Tamil loanwords, as does classical Malay (Hoogervorst in press a). ${ }^{1}$ From at least the ninth century, Tamil inscriptions surface across Southeast Asia (Karashima and Subbarayalu 2009), while different Indian ethnonyms

1 And see Ronkel (1902), Asmah (1966), and Jones (2007) on Tamil loans in modern Malay. 
start to feature in the Old Javanese literature around the same time (Christie 1999). For example, early eleventh century Airlangga inscriptions make a distinction between Kling, Āryya, Singhala, and Karṇațaka (Krom 1913), while the mid-fourteenth century Nāgaraksrtägama adds Goḍa and Kãñcipurī (Pigeaud 1962: 36). South Indian influence is especially strong in North Sumatra. The Dutch orientalist Van Ronkel (1918) was the first to call attention to a number of cultural and lexical peculiarities among the Karo-speaking Sembiring clan, which he connected to the historical presence of Tamil trading guilds in the region. Recent archaeological research supports the settlement of South Indian populations in North Sumatra in medieval times (Guillot and Fadillah 2003; Perret and Surachman 2009). In later times, multi-ethnic Islamic networks between South India, Sri Lanka and the Malay World begin to overshadow earlier Hindu and Buddhist connections ('Ālim 1993; Tschacher 2001; Feener and Sevea 2009; Ricci 2011).

The South Indian populations in contact with Maritime Southeast Asia were diverse in terms of religion and caste. By the fourteenth century, Tamil-speaking Muslim communities started to outnumber their Hindu compatriots (McPherson 1990). The first group was then commonly known as Kling or Keling. This ethnonym is probably connected to the Kalinga State in present-day Odisha and would later become the generic name for "Indian", even applied to some Indianized communities in Southeast Asia (compare Damais 1964; Mahdi 2000: 848). At present, the term is regarded as pejorative across the Malay-speaking world. The collective term for South Indian Muslim traders was Chulia or Chuliah. ${ }^{2}$ The Chulia were seen as distinct from mercantile Muslim groups from Gujarat and other western regions of India, such as the Khojā and the Bohrā (compare Hussainmiya 1990; Noor 2012). ${ }^{3}$ South Indian Muslim communities display a substantial and at times confounding terminological variety (Bayly 1989; 'Ālim 1993; Tschacher 2001; Hussein 2007; Pearson 2010). One of the terms used for them by non-Muslim Tamils is Jōnagan (சோனகன்), which is especially applied to Muslims of partly Arabic or Turkish descent. The colonial British censuses typically distinguish the following subgroups of South Indian Muslims:

\section{Marakkar or Maricar (Tamil: Marakkāyar; மரக்காயர், Malay: Marikar)}

A group claiming ancestry from Arabic merchants, as opposed to less esteemed local converts. They were mostly involved in international shipping trade, inhabited coastal regions, and adhered to the Shäficī school (maddhab) of Islamic jurisprudence (figh). The Kāyalār, from the coastal town Kāyalpațtinam, are normally considered to be a subgroup of the Marakkāyar.

2 Malay Culia, Tamil Cüliyā (குலியா). The origins of this term are uncertain. See Khoo (2014) for a history of the Chulia community in Penang.

Hindu merchants from Gujarat were known as Baniyān. 
2. Labbai or Labbay (Tamil: Labbai; லப்பை, Malay: Ləbai)

Originally an honorary term for an Islamic functionary, ${ }^{4}$ but later used to designate a particular Tamil-speaking community of the Hanafì maddhab. They were traditionally involved in trade, pearl-diving and betel-cultivation. The term Labbai is also occasionally applied to non-Marakkāyar Tamil-speaking Muslims as a whole.

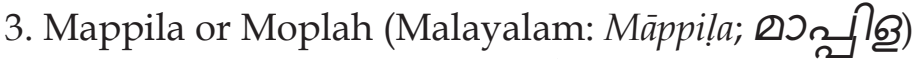

Malayalam-speaking Muslims of partly Arabic ancestry who chiefly resided in the Malabār region (present-day Kerala). The majority follow the Shāfici maddhab.

\section{Muslims "from the north"}

A container term for predominantly Urdu-speaking Muslims residing in different parts of South India, encompassing the ethnonyms Navaiyat, Sayyid, Shaykh and Pathān. These groups claim be descended from non-Dravidian men in service of the Mughal and Deccan sultans. Special mention can be made of the Rowthers (Tamil: Rāvuttar; ராவுத்தர்), a Tamil-speaking group of the Hanafī maddhab claiming descent from Turkish (Tulukkar; துலுக்கர்) horsemen.

Many Indian merchants who ventured to Southeast Asia married local women. The affluent and influential mixed community that thus emerged became known in Malay as the Jawi Pranakan 'local-born Jawi'. ${ }^{5}$ These children of merchants were well-connected with the Muslim elites in Southeast Asia and beyond (Fujimoto 1989). In the Straits Settlements, their multilingual background, including in English, qualified them for lucrative employment under the colonial government. They were also involved in the printing press. In 1876, a Singapore-based Malay printing office under the name Jawi Pranakan published - at the same time - Southeast Asia's first Tamil and first Malay newspaper (Birch 1969; Tschacher 2009). ${ }^{6}$ In Aceh, mixed people of Tamil ancestry - mentioned by Snouck Hurgronje (1893: 20) as basterd-Klinganeezen - appear to have largely assimilated into the Acehnese mainstream, being only recognizable on a phenotypical level. A still existing hybrid group are the so-called Chitty (Tamil: Cițti; சिட்டி), the offspring of Kaling fathers and Malay mothers in Malacca. Their name goes back to Chetty (Tamil: Cețtii; செட்டி, Malay: Ceti), a term loosely applied to a number of South Indian mercantile castes and money-lenders in the Malay World. The Chitty people have kept their Hindu

$4 \quad$ In Sri Lanka Malay, lebbe still refers to an Islamic scholar (Saldin 1993: 1015). In Indonesia, labai typically refers to a mosque official.

5 In Penang, the term Jawi Pakan 'urban Jawi' is more common. The word Jawi presumably goes back to Arabic Jāwì, an umbrella term for Malays and other Southeast Asian Muslims.

The Tamil newspaper was named Tangai Sinê̄han (தங்கை சினேகன்), the Malay newspaper Jawi Peranakan. Contrary to popular belief, the latter was not the world's first Malay newspaper. Already in 1869, the Alamat Langkapuri was issued in Colombo, Sri Lanka, by a member of the Malay diaspora (Ricci 2013). 
religion to this day, yet can be considered Malay in terms of language and culture (Raghavan 1977). ${ }^{7}$ In post-independence Malaysia, however, Chitties have thus far been unsuccessful in claiming bumiputra-ship, whereas most Muslim Jawi Peranakan conveniently registered themselves as Malays. ${ }^{8}$

Cultural contact between South and Southeast Asia persisted into modern times. While the British Government had a long tradition of employing Indian personnel in the Straits Settlements, the late nineteenth century saw a substantial increase of labour migration from South India to the Malayan rubber plantations and tea estates. This led to an influx of Indian Tamils, Sri Lankan Tamils, Malayalis, Telugus, and other South Asian communities, then known as 'coolies' (Tamil: küli; கூ ல)). This system of indentured labour depended on local recruiters and became known as the "kangani system" (compare Guilmoto 1993), from the Tamil word kangāṇi (கண்காணி) 'supervisor of coolies in plantations'. Around the same time, the Dutch relied on agricultural labourers from South India and other regions to work on the infamous estates of Deli in northern Sumatra (Mani 1993a). The cultural crossfertilization between South and Southeast Asian populations in Malaysia, Singapore, southern Thailand and parts of Sumatra led, among other things, to the emergence of a mixed Indian-Malay cuisine known as mamak food, from the Tamil word māmā (மாமா) 'uncle'. Popular dishes include roti canai 'layered flatbread', murtabak or martabak'stuffed pancake', nasi kandar 'steamed rice with various curries', mamak rojak 'fruit and vegetable salad' and teh tarik 'pulled tea'.

\section{LITERARY CONNECTIONS}

In the light of the trans-regional Islamic networks across the Bay of Bengal, it is not surprising to see South Indian influence reflected in the classical Malay literature. The Hikayat Sari Rama - the Malay version of the Rāmàyana - for example, displays some uncommon Tamil words. One example is $c-n g-g-l-n-r$ 'a type of water-lily with miraculous powers', which reflects Tamil cengalunir (செங்க ழநீர்) 'purple Indian water-lily; red Indian water-lily' (compare Von de Wall 1877-97, appendix: 24; Van Ronkel 1902: 107). Other examples are parwadam 'mountain' from Tamil parvadam (பர்வதம்) (Juynboll 1899: 66) and trrisulam 'trident' from tirisūlam (திரிகுலம்) (Van Ronkel 1919: 383). The names of some of the characters, too, suggests that the hikayat contains Tamil influence (Table 1).

7 The fact that the Chitties have never converted to Islam would either imply that not all Malays were Muslims by the time this hybrid group emerged, or that interreligious marriages were historically seen as less problematic in the Malay World than they are at present (Raghavan 1977: 444-445).

${ }_{8}$ Being registered as Bumiputra 'Son of the Soil' comes with various types of ethnicitybased state benefits (Kessler 1992). In nationalist circles, however, there was no small degree of resentment to the practice among hybrid Indian Muslims (darah katurunan Kaling) to claim Malay status (Hussain 2005: 124). 


\begin{tabular}{|l|l|l|}
\hline Malay & Tamil & Sanskrit \\
\hline Baradan & Baradan (பரதன்) & Bharata \\
\hline Kikukan & Kukan (குகன்) & Guha \\
\hline Nikumbili & Nikumbalai (நிகும்பலை) & Nikumbhilā \\
\hline Surapandaki & Sūrppaṇakai (குர்ப்பணை) & Sūrpaṇakhā \\
\hline Səri Jati & Tirijațai (திரிசடை) & Trijațā \\
\hline Bibusanam & Vibișaṇañ (விபிஷணன்) & Vibhīṣaṇa \\
\hline
\end{tabular}

Table 1. Tamil names in the Hikayat Sori Rama (Juynboll 1899; Muniandy 1995).

\begin{tabular}{|c|c|}
\hline Malay & Tamil \\
\hline Anji-w-n-t-r & Añjuvañattār (அஞ்சுவனத்தார்) \\
\hline Bijayanagaram & Vijayanagaram (விசயநகரம்) \\
\hline Cit-m-b-ram & Cidambaram (சிதம்பரம்) ${ }^{10}$ \\
\hline Kh-l-y-k-t ${ }^{11}$ & Kōlikkōṭu (கோழிக்கோடு) $)^{12}$ \\
\hline K-n-di & Kaṇdi (கண்டி) $)^{13}$ \\
\hline K-s-n-r-y-n & Kirușnarāyan̄ (கிருஷ்ணராயன்) \\
\hline K-s-t-r-y-n & Kșattiriyan̄ (கூఖத்திரியன்) \\
\hline M-1-wari & Malabāri (மலபாரி) \\
\hline N-1-s-ng-kun ${ }^{15}$ & Narasingan̄ (நரசிங்கன்) \\
\hline
\end{tabular}

Table 2. Tamil names in the Hikayat Hang Tuah.

The Hikayat Hang Tuah contains more clues to Tamil influence on the classical Malay literature. During his diplomatic journey to the Tamil Land (Bәnua Kaling), the story's protagonist surprised his hosts with his fluency in Tamil,

9 This form is evidently rationalized as consisting of the Malay honorific Sori, which is Sanskrit Śrì.

10 This is the name of a famous Shaiva shrine in the Arcot district. The word was left unidentified by Van Ronkel (1904: 315) and is commonly transliterated as the meaningless compound sitam brama in later editions of Hikayat Hang Tuah.

11 Van Ronkel (1904: 314) regards this form as a misspelling of P-l-y-k-t (Pulicat).

12 Presumably the city of Calicut.

13 This presumably denotes the city of Kandy (Sri Lanka), although Van Ronkel (1904: 314) connects it to the Kannada community in South India.

14 Reflecting Sanskrit Krș̣narāja, a common title for South Indian kings.

15 At present, this name is typically transliterated as Nala Sang Guna, which makes little etymological sense. 
which he proclaimed to have learned from a Labai from that country. As first pointed out by Van Ronkel (1904), here too we find a number of Tamil-derived onomastics and caste names. Table 2 above lists the Jawi transliterations and their tentative precursors.

A third Malay literary work that casts some light on Malay notions of India is the Hikayat Parintah Nagari Banggala. This text, written in 1811 by the Chulia author Ahmad Rijaluddin, contains a number of uncommon Tamil loanwords, such as bangku 'dagger' from vānkku (வாங்கு) and banam 'rocket' from vānam (வாணம்) (Skinner 1982: 168, 173). In addition, we come across a number of Malay names for South Indian toponyms (Table 3), although it is uncertain what role, if any, these places play in the popular Malay imagination of those days.

\begin{tabular}{|l|l|l|}
\hline Malay & Tamil & English \\
\hline Harkat & Ārkāțu (ஆற்காடு) & Arcot \\
\hline Macəli & Maccilippațțanam (மச்சிலிப்பட்டணம்) & Masulipatam \\
\hline Mahu & Māhē (மாஹே) & Mahé \\
\hline Naga Patan & Nāgappațịnam (நாகப்பட்டினம்) & Negapatam \\
\hline Nagor & Nāgūr (நாகூர்) & Nagore \\
\hline Tanjauru & Tañjāvūr (தஞ்சாவூர்) & Tanjore \\
\hline Tipu ${ }^{16}$ & Srīrañgappaț̣anam (ஸ்ரீரங்கப்பட்ணம்) & Seringapatam \\
\hline
\end{tabular}

Table 3. Malay names for Tamil toponyms in the Hikayat Parintah Nagari Banggala (Skinner 1982: 26).

Muslims of mixed Malay-Tamil ancestry were often bilingual if not multilingual. By the late nineteenth century, they typically published both Tamil and Malay newspapers in Sri Lanka (Hussainmiya 2008) as well as the Malay World. In the Straits Settlements, Jawi Paranakan children would have learnt Malay from their mothers and Tamil from private tutors (Fujimoto 1989: $98 \mathrm{fn} .18)$. This is confirmed in the writings of the famous early nineteenthcentury Munshi Abdullah, a Malacca-born author of mixed origins who grew up in a district known as Kampung Pali (Tamil: palli; பள்ளி) - 'Kampung of the Mosque' - a historical part of Malacca known for its mixed population. In his mid-nineteenth century autobiography named Hikayat Abdullah, he wrote that "it had been the custom from the time of our forefathers in Malacca for all the children of good and well-to-do families to learn it [Tamil]. It was useful for 
doing computations and accounts, and for purposes of conversation because at that time Malacca was crowded with Indian merchants. Many were the men who had become rich by trading in Malacca, so much so that the names of Tamil traders had become famous. All of them made their children learn Tamil" (translation from Hill 1955: 48).

The tradition of multilingualism among the literate elite led to a degree of convergence between Islamic Malay and Tamil literature. As previous scholars have pointed out ('Ālim 1993: 95-99; Tschacher 2009: 53-54; Ricci 2011: 174), these shared origins become evident upon comparing the ways in which sounds absent in the Arabic alphabet are represented in Arabized Malay (Jawi) and Arabized Tamil (Arwi). This is done in a remarkably similar way, with minor differences on a diacritical level: the voiceless bilabial stop $/ \mathrm{p} /$ is written as $f \bar{a}^{\prime}\langle\omega\rangle$ with three upper dots in Jawi and with one lower dot in Arwi, the velar nasal $/ \mathrm{n} /$ as 'ayn $<_{\varepsilon}>$ with three upper dots in Jawi and with three lower dots in Arwi, and the palatal nasal $/ \mathrm{n} /$ as nün $\langle\dot{u}>$ with three upper dots in Jawi and two lower dots in Arwi. It should be noted here that the Arabicized writing practice dates back to the early fourteenth century in the Malay World, whereas it presumably developed around the late sixteenth century in the Tamil-speaking areas of South India (Tschacher 2001: 27; Ricci 2011: 98), cautioning researchers not to assume an a priori eastward directionality of cultural transmission.

Regrettably, it is not known how many multilingual or otherwise hybrid manuscripts are housed in public and private libraries worldwide. In the late nineteenth-century, there is some circumstantial evidence that the Acehnese kept their administrations records in Klingaleesch, to wit, Tamil (Scherer 1891: 298). One of these manuscripts is mentioned by Voorhoeve (1952: 212) in his inventory on Indonesian manuscripts at the Leiden University Library. That same library also houses the 'Izām al-fawa'id fi nizām al-'aqā'id, a 1730s manuscript written partly in Tamil and partly in Malay (Van Ronkel 1922; Tschacher 2009: 54). 'Âlim (1993: 105-106) calls attention to "a book on Muslim Medicine edited in 1807 AD [...] written in four languages: Javanese (Javi) [sic!], Persian, Arwi and Arabic" kept in the "Indonesian Manuscript Library at Jakarta", which is likely to be the same manuscript (B.A. Hussainmiya, personal communication on 12 December 2014). This multilingual Islamic tradition may have persisted into recent times. An undated but modernlooking manuscript discovered in 2008 by Mahyudin Syukri and Siti Aisyah in Balai Jering (Kampar, Riau Province, Indonesia) contains a quadrilingual word-list - Arabic, Malay, Urdu and Tamil - written by a local Muslim scholar (Aisyah 2014). It is hoped that similar works will surface in private collections in Indonesia, Malaysia and Sri Lanka.

\section{THE MALAY USED BY TAMILS}

The Malay varieties spoken by communities of Chinese ancestry are relatively well-documented, for example, Lim (1981), Pakir (1986), and Gwee (2006) on "Baba Malay" of the Straits Settlements, Teo (2003) on the variety of 
Kelantan, Rafferty (1982) on Malang, Oetomo (1987) on Pasuruan, and Wolff and Poedjosoedarmo (1982) on Central Java. The same cannot be said of varieties spoken by Indian communities. Mohamed (2006) describes the lexicophonology of the dialect belonging to the Chitty community, whereas Hassan (1969) and Kader (1971) provide some notes on colloquial Malay as spoken by Tamils. While the majority of local-born Indians speak Tamil at home and some have switched to English, a small part of this group have adopted the Malay language. ${ }^{17} \mathrm{~A}$ systematic study on Malay as spoken by people of South Indian ancestry, however, remains to be conducted to this day.

Research on errors (kasalahan) in Malay offers an otherwise infrequent glimpse into the Malay speech habits of Tamils. I can only give an incomplete set of isolated examples from the sources available to me. On a phonological level, the following tendencies, some of which inconsistent, are observed among Tamil pupils in Malaysian schools (Gan 1982, quoted in Onn 1989: 78-79):

(1) Omission of /h/

$\begin{array}{ll}\text { boleh } & >\text { bole 'can' } \\ \text { hisap } & >\text { isap 'to suck' } \\ \text { hujan } & >\text { ujan 'rain' } \\ \text { puluh } & >\text { pulu 'ten' } \\ \text { sudah } & >\text { suda 'already' } \\ \text { tahun } & >\text { taun 'year' }\end{array}$

(2) Substitution of / $/$ by $/ \mathrm{a} /, / \mathrm{e} /$ or $/ \mathrm{i} /{ }^{18}$

$\begin{array}{ll}\text { ampat } & >\text { ampat 'four' } \\ \text { onam } & >\text { anam 'six' } \\ \text { pəcah } & >\text { pica 'broken' } \\ \text { salalu } & >\text { silalu 'always' } \\ \text { sandiri } & >\text { sindri 'self' } \\ \text { təmpat } & >\text { tempat 'place' } \\ \text { torus } & >\text { terus 'direct' }\end{array}$

(3) Gemination of word-medial stops

apa $>$ appa 'what'

sadikit $>$ siddikit'a little'

17 In 2005, 10.6\% of Singapore's Indian population spoke Malay at home (Aman et al. 2009). The Malaysian statistics are unknown to me.

18 All three variations are attested, for example, in the Tamil renditions of Malay toponyms: Kəlantan (Kilāntān̄; கிளந்தான்), Məlaka (Malākkā; மலாக்கா), Nəgəri Səmbilan (Negiri Sembilān;; நெகிரி செம்பிலான), Pərlis (Perlis; பெர்லிஸ்), Tərəngganu (Tirañgāñu; திராங்கானு). 
(4) Devoicing of /g/

$\begin{array}{ll}\text { gatah } & >\text { keta 'rubber' } \\ \text { goreng } & >\text { koring 'to fry' } \\ \text { tiga } & >\text { tika'three' }\end{array}$

(5) Fricativization of $/ \mathrm{w} /$

wang $>$ van [vang?] 'money'

wayang $>$ vayang 'movie'

(6) Monophthonization of /ai/

kadai $>$ kede 'shop'

Gan (1982) gives no examples on the pronunciation of the diphthong / au/. Mohamed (2006: 88-89) mentions in passing that kalau 'if' is pronounced as kalu by Tamil speakers. ${ }^{19}$ She also lists two examples which make it clear that the glottal stop / / at the end of a syllable - written in Malay as $<\mathrm{k}>-$ is omitted by Tamil mother tongue speakers: anak > ana 'child' and kakak > kaka 'older sister'. In addition, it has been pointed out that Tamil-speakers pronounce orang 'person' as worang and barang 'goods' as bareng (Hassan 1969: 218). Both examples can be explained through the phonology of colloquial Tamil. The automatic onset of / w/ before close and close-mid back vowels is common across spoken Tamil varieties (Schiffman 1999: 16). In certain dialects, the word-final ending -/aN/ is pronounced as -/ẽ/ (Schiffman 1999: 18), which would explain the transcription of bareng for standard Malay barang. No further examples are given by Hassan (1969) or other scholars to determine the distribution and regularity of this phonological tendency.

On a grammatical level, Kob (1989: 495) provides the following examples of interference from colloquial Tamil on the word order of spoken Malay (here and elsewhere: the spelling, translations and glosses are mine):

\begin{tabular}{lllr} 
(7) Itu & saya & punya & \multicolumn{1}{c}{ suka=lah } \\
DEM & 1sG & POS & like=PART \\
Inda & enudaiya & viruppam & (Tamil) \\
DEM & 1sG.GEN & desire &
\end{tabular}

'That's the one I like.'

(standard Malay: Saya suka itulah.)

(8) Api kareta jalan sudah

fire cart go already 


$$
\begin{array}{lll}
\text { Pugai=vandi } & \text { poyy=vittadu } & \text { (Tamil) } \\
\text { Fire=cart } & \text { go=leave.PST } &
\end{array}
$$

'The train has departed.'

(standard Malay: Kareta api sudah jalan.)

However, the latter example may also reflect a Hokkien structure (Kob 1989: 495):

(9) Hóe chhia kiân liáu

$\begin{array}{llll}\text { 火 } & \text { 車 } & \text { 行 } & \text { 了 } \\ \text { fire } & \text { cart } & \text { go } & \text { already }\end{array}$

Rather than dismissing these phonological and syntactic patterns as erroneous, Hassan (1969) introduces the term 'Tamil Bazaar Malay' (Bahasa Molayu Pasar Tamil) and lists a number of characteristics. While the noun phrase-initial position of the demonstratives - as seen in example (7) - is quite common cross-linguistically and could reflect interference from Tamil, Hokkien or other languages, the clause-final position of the verb in Tamil Bazaar Malay specifically points to Indian influence. ${ }^{20}$ Hassan (1969: 212) provides the following examples:

(10) Ahmad pokok panjat

Ahmad tree climb

'Ahmad climbs a tree.'

(standard Malay: Ahmad məmanjat pokok.)

(11) Itu budak bola sepak

DEM kid ball kick

'That kid kicks a ball.'

(standard Malay: Budak itu mənyepak bola.)

In addition to clause-final verbs, Tamil and many other Indian languages also display postpositions instead of prepositions. This impacts on the Malay they use, as Mohamed (2006: 13) demonstrates in an isolated example:

(12) Saya rumah misjid balakang juga ada

1sG house mosque behind also is

'I also have a house behind the mosque.'

(standard Malay: Saya juga ada rumah di bolakang masjid.)

20 The basic SOV word order is common in Indian languages of various families, including Dravidian and Indo-Aryan. 
Other characteristics of Tamil Bazaar Malay include a set of distinct personal pronouns and the use of the particle punya as a possessive marker. These features are shared with several other Malay contact varieties and will be addressed in more detail in the next section. Hassan (1969: 214) provides the following examples in Tamil Bazaar Malay:

(13) Saya punya rumah basar punya anjing ada 1sG POS house big POS dog is

'There is a big dog in my house.'

(standard Malay: Di rumah saya ada səekor anjing basar.)

(14) Saya punya rumah puteh (ada)

1sG POS house white (is)

'My house is white.'

(standard Malay: Rumah saya barwarna putih.)

In a MA thesis on Malay spoken by Tamils, Kader (1971: 446, quoted in Mohamed 2006: 31) provides some additional examples displaying the abovementioned features:

(15) Ittu jam worang tarak banyak

DEM hour people NEG many

'Not many people were around at that hour.'

(16) Ittu ujan tara branti, sampe sattu ari po wora DEM rain NEG stop so.that one day PART people

tara kitta diyam sajja

NEG 1PL still PART

'It was raining non-stop, so that nobody showed up for the entire day [and] we had nothing to do.'

The above examples reflect difficulties in terms of transcription. For example, the negative marker tarak occurs alongside tara and worang 'people' is found alongside wora. The forms <wora> and < po> presumably represent / worã/ (orang) and / põ/ (the particle pun). A more systematic phonological analysis of Malay spoken by Tamils, which also addresses the conditions of intervocalic consonant gemination, may help us make sense of these inconsistencies. 


\section{BAZAAR MALAY AND OTHER CONTACT VARIETIES}

As mentioned in the previous section, some of the characteristics of colloquial Malay spoken by Tamils are attested more widely, especially in what is known as "Bazaar Malay" - the container term for Malay contact varieties not spoken as a mother tongue. The Malaysian Tamils presumably learnt this basilectal variety for out-group communication. Studies on West Malaysian Bazaar Malay are not well-distributed beyond a local level and often remain unpublished (Hassan 1969: 210 fn. 3). On the Singaporean variety, Daw (2005) offers the most complete description. Across West Malaysia, Bazaar Malay is spoken by Tamils and Chinese as a contact language. Its personal pronouns (see Table 4), resemble those of other "pidgin-derived Malay varieties" ${ }^{21}$

\begin{tabular}{|l|l|l|}
\hline & singular & plural \\
\hline 1 & gua & kita (orang) \\
\hline 2 & lu & lu orang \\
\hline 3 & dia & dia orang \\
\hline
\end{tabular}

Table 4. Bazaar Malay pronominal paradigm (Hassan 1969: 216).

The Bazaar Malay personal pronouns reflect Chinese influence. The 1sG goes back to Hokkien góa (我), whereas the 2sG reflects dialectical Hokkien lú (汝) in the same meaning. The use of orang as a plural marker corresponds to lâng (人 or 儂) in some Hokkien dialects, including in the original meaning of 'person; people'. This usage is also found in Chitty Malay (Mohamed 2006), Baba Malay (Gwee 2006), Sri Lanka Malay (Nordhoff 2009), Cocos Malay (Adelaar 1996) and several Eastern Indonesian Malay varieties (Paauw 2008). Sri Lanka Malay, along with other Malay varieties, also displays other loanwords from Hokkien, including lo:teng 'storey, floor' and ku:we 'breakfast' (Paauw 2004: 45). ${ }^{22}$ Other tentative Chinese loans attested as far as Sri Lanka include bangsat 'bedbug' and bopeng 'pock-marked' (compare Saldin 1993). ${ }^{23}$ This implies that the Chinese played some role in the making of a vehicular Malay trade variety. On a grammatical level, this is corroborated by the use of punya as a possessive marker, which is attested in roughly the same pidgin-derived Malay varieties as the above-mentioned Chinese-derived personal pronouns. Pakir (1986: 141-162) demonstrates that the use of mia in Baba Malay - which goes back to punya - largely mirrors the Hokkien syntax:

21 In a paper on the language history of Malay, Adelaar and Prentice (1996) distinguish "literary Malay varieties", "pidgin-derived varieties", and "Malayic vernaculars". This distinction roughly corresponds to 'written Malay' (Bahasa Məlayu Tulisan), 'regional Malay' (Bahasa Məlayu Daerah) and 'spoken Malay' (Bahasa Məlayu Lisan), and 'Bazaar Malay' (Bahasa Malayu Pasar) proposed by Hassan (1969).

${ }_{22}$ Reflecting lâu-téng (樓頂) 'upper storey, upstairs' and kóe (粿) 'cakes'.

23 Presumably from Hokkien bák-sat (木虫) and mô-pang (麻斑). 
$(17)$

$\begin{array}{llll}\text { Dia } & \text { mia } & \text { monantu } & \text { (Pakir 1986: 141) } \\ I & \hat{e} & \text { sin-pu } & \text { (Hokkien) } \\ \text { 伊 } & \text { 的 } & \text { 新婦 } & \\ \text { 3SG } & \text { POS } & \text { daughter-in-law } & \end{array}$

'His daughter-in-law'

(18)

$\begin{array}{lllll}\text { Kasi } & \text { gua } & \text { wangi } & \text { mia } & \\ \text { Hō } & \text { góa } & \text { pang } & \hat{e} & \text { (Hokkien) } \\ \text { 予 } & \text { 我 } & \text { 方 } & \text { 的 } & \\ \text { give } & \text { 1sG } & \text { fragrant } & \text { POS } & \end{array}$

'Give me the fragrant one.'

(19) Ini bukan sabarang mia (Pakir 1986: 161)

Chit-lé $\bar{m}$-sì chin-chhái $\hat{e} \quad$ (Hokkien)

這禮册是清采的

DEM NEG careless POS

'This is not careless(ly done).'

However, the use of the possessive marker punya is by no means limited to Chinese and Chinese-influenced varieties. In a paper on Sri Lanka Malay, Jayasuriya (2002: 49) provides an example in which Sri Lanka Malay, colloquial Sinhala and Sri Lanka Tamil are syntactically identical (the spelling is mine):

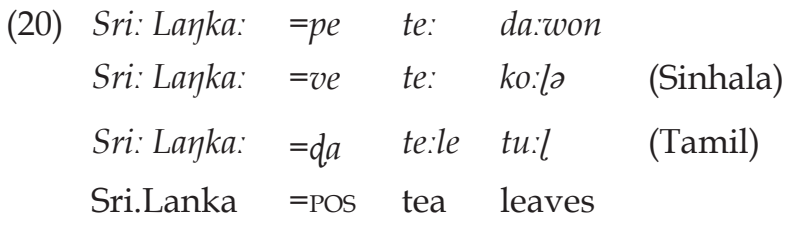

'Sri Lankan tea leaves'

Of the substandard Malay varieties in contact with Tamil, Sri Lanka Malay has received the most academic attention. This variety has an estimated 46000 speakers (Jayasuriya 2002) and its survival is threatened by Sinhala, Sri Lanka's national language. This Malay variety is spoken by the descendants of soldiers, convicts, slaves and exiles who came to the country from the mid-seventeenthcentury onwards, both under Dutch and British rule. These "Malays" came from various places, but the mainstream dialect bears a strong resemblance to East Indonesian Malay, while also displaying some Jakartan influence (Adelaar 1991; Paauw 2004). In-depth analyses of Sri Lanka Malay and its origins are of recent date (Nordhoff 2009, 2014; Slomanson 2011). It has often been argued that Sri Lanka's Malay population was in close contact with other Muslim communities. Muslims in Sri Lanka constitute a rather diverse demographic 
segment, including Malays, groups from Northwest India, ${ }^{24}$ and the so-called "Moors". The term Moor historically referred to Muslims in general and is not regarded as particularly derogatory in a Sri Lankan context. It specifically denotes Tamil-speaking Muslims, who generally do not consider themselves Tamils. Sri Lankan Malays, too, see them as distinct communities; they call the former Keling and the latter Mulbar (Saldin 1993).

Aside from a rather brief description (Hussein 2007: 40-48), systematic and well-distributed linguistic research on the Tamil variety of the Moors - known as Shonam or Sonam and traditionally written in Arwi script - is lacking to this day. ${ }^{25}$ There appear to be at least two distinct dialects, one spoken by the inland 'Sri Lankan Moors' or Sōnahar and one by the coastal 'Indian Moors' or Sammankārar (Nuhman 2007: 25; Hussein 2007: 473). ${ }^{26}$ Most scholars of Sri Lanka Malay believe that the language received significant grammatical influence from Shonam. A counterview has been proposed by Ansaldo (2008), who takes issue with what he calls the "Tamil bias" and contends that the rather atypical grammatical features of Sri Lanka Malay may equally well reflect Sinhala influence. While descriptions of Sri Lanka Malay occasionally contain elicited Shonam data (Jayasuriya 2002; Slomanson 2011), this variety deserves a systematic description in its own right if we are to advance the discussion of Sri Lanka Malay origins (Ansaldo 2014: 383-384).

A number of typological features of Sri Lanka Malay can be attributed to Tamil (or Sinhala) influence. These include consonant gemination, the presence of long vowels, SOV word order, postpositions, adjectives preceding nouns, and suffixed conditions (Adelaar 1991; Jayasuriya 2002; Paauw 2004). As we have seen in the previous section, several of these features also occur in Bazaar Malay used by Tamil speakers. Other characteristics of Sri Lanka Malay, such as the position of the demonstratives and the use of a possessive marker, are quite common cross-linguistically - in particular in contact languages - and are therefore poor markers of contact-induced borrowing (compare Ansaldo 2008). Likewise, the omission of / h/ in Sri Lanka Malay (see Saldin 1993: 1001), which could point towards Tamil influence, presumably already took place in the Malay World, where it is quite common across dialects.

As mentioned previously, Sri Lanka Malay bears the greatest typological resemblance to the pidgin-derived varieties of East Indonesia. Paauw (2008) highlights a set of features shared by the varieties of Manado, North Maluku, Ambon, Banda, Kupang, Larantuka and Papua, which he argues go back to an historical "Eastern Indonesian Trade Malay". In summary, these include: the monophthongization of /au/ to /o/ and / ai/ to /e/, the loss of /h/, the loss of the glottal stop at the end of a syllable, the lowering of /i/ to /e/ and $/ \mathrm{u} /$ to $/ \mathrm{o} /$ in closed final syllables, the use of punya or a derived form

24 These include the so-called Memon from the Sindh region and the aforementioned $\underline{K} h o j a \bar{a}$ and Bohrā, who migrated to Sri Lanka in colonial times (Hussainmiya 1990).

25 Shonam corresponds to standard Tamil Cōnam (சோன ம்), a term denoting Muslims or (other) foreigners.

26 Corresponding to standard Tamil Cōnakar (சோனகர்) and Cammānnkārar (சம்மான் காரர்) 'sampan-men', the latter having been borrowed into Sinhala as Hambankārayā. 
as a possessive marker, the shortening of the demonstratives ini 'this' and itu 'that' for discourse strategies, plural pronouns formed with orang, and tara as a negative particle. Interestingly, several of these features are also found in Bazaar Malay, Chitty Malay, Baba Malay, Sri Lanka Malay, Cocos Malay, and colloquial Indonesian (compare Adelaar 2005). Regardless of whether we prefer the term "pidgin-derived Malay varieties", "contact varieties", "trade Malay" or "vehicular Malay", it is important to keep in mind that varieties displaying this largely shared set of features are geographically attested throughout the Malay speech area - often in a diglossic continuum with standard Malay.

In addition to these shared grammatical features, Malay contact varieties - including colloquial Indonesian - exhibit a set of lexical discrepancies from the acrolectal, inherited varieties of Sumatra and West Malaysia, which stood at the cradle of standardized Malay. In other words, the vocabulary shared by pidgin-derived Malay varieties across a broad geographical range indicates a common origin. Some examples are given in Table 5.

\begin{tabular}{|l|l|l|l|l|}
\hline $\begin{array}{l}\text { Baba Malay } \\
(\text { Gwee 2006) }\end{array}$ & $\begin{array}{l}\text { Sri Lanka Malay } \\
\text { (Paauw 2004) }\end{array}$ & $\begin{array}{l}\text { Colloquial } \\
\text { Indonesian }\end{array}$ & $\begin{array}{l}\text { Inherited } \\
\text { Sumatran /West } \\
\text { Malaysian Malay }\end{array}$ & Gloss \\
\hline bikin & bi:lang & bikin & buat & 'to do, to make' \\
\hline bilang & & buntut & ekor, punggung & 'tail, rear part' \\
\hline buntot & capek & lətih, pənat & 'tired' \\
\hline $\begin{array}{l}\text { capek ('lame, } \\
\text { limping') })^{27}\end{array}$ & ca:pe & dia orang & məreka & 3sG \\
\hline dia orang & derang & dukun & bidan, bomoh & 'medical healer, \\
midwife'
\end{tabular}




\begin{tabular}{|l|l|l|l|l|}
\hline $\begin{array}{l}\text { Baba Malay } \\
\text { (Gwee 2006) }\end{array}$ & $\begin{array}{l}\text { Sri Lanka Malay } \\
\text { (Paauw 2004) }\end{array}$ & $\begin{array}{l}\text { Colloquial } \\
\text { Indonesian }\end{array}$ & $\begin{array}{l}\text { Inherited } \\
\text { Sumatran /West } \\
\text { Malaysian Malay }\end{array}$ & Gloss \\
\hline pi & pi: & $\begin{array}{l}\text { (compare } \\
\text { several Malay } \\
\text { dialects: pi } ~ \\
\text { pigi) }\end{array}$ & pərgi & 'to go' \\
\hline piara & piya:ra & piara & pəlihara & 'to take care of' \\
\hline tarok & ta:ro & taruh & lətak & 'to put' \\
\hline $\begin{array}{l}\text { təman ('female } \\
\text { slave or } \\
\text { nanny' }\end{array}$ & tuman & təmən & kawan & 'friend' \\
\hline
\end{tabular}

Table 5. Some lexical similarities in Malay contact varieties.

Sri Lankan Malay has also adopted some Tamil words at the cost of their Malay equivalents (Table 6).

\begin{tabular}{|l|l|l|l|}
\hline Sri Lanka Malay & Tamil & Standard Malay & Meaning \\
\hline kusni & kusiñi (குசினி) & dapur & 'kitchen' \\
\hline mami & māmi (மாமி) & bibi & 'aunt' \\
\hline nondi & noṇḍi (நொண் டி) & pincang & 'lame' \\
\hline wauwal & vavvāl (வவ் வால்) & kəlawar & 'bat' \\
\hline
\end{tabular}

Table 6. Tamil loans in Sri Lanka Malay (Hussein 2007: 419).

More Tamil loans in Sri Lanka Malay are given in Scott Paauw's MA thesis on the lexical origins of Sri Lanka Malay (2004). Some of the words listed in this study appear to display phonological innovations specific to Shonam (compare Hussein 2007), providing some further support to the hypothesis that the latter had influenced the former to a considerable extent. This again underlines the need for an accurate description of this variety if the discussion of Sri Lanka Malay origins is to be taken any further. A modest number of examples are given in Table 7.

\begin{tabular}{|l|l|l|l|}
\hline Sri Lanka Malay & Shonam & Literary Tamil & Meaning \\
\hline bla:ngga & bulāniga & vilāñnāy (விளாங் காய்) & 'wood-apple' \\
\hline mawen & mavan & magan (மகன்) & 'boy, son' \\
\hline mawol & maval & maga! (மகள்) & 'girl, daughter' \\
\hline
\end{tabular}

Table 7. Shonam loans in Sri Lanka Malay.

28 Borrowed from Tamil taman (தமன்) 'male relative or friend'. 
Other Tamil loans in Sri Lanka Malay appear to go back to another type of colloquial Tamil, whose precise dialectical origins remain obscure. Some examples taken from Paauw (2004) are listed in Table 8; the envisioned dialectical Tamil etyma are mine.

\begin{tabular}{|l|l|l|l|}
\hline Sri Lanka Malay & dialectical Tamil & literary Tamil & meaning \\
\hline e:pong & *e:ppõ & ēppam (ஏப்பம்) & 'burp, hiccup' \\
\hline konyong & *konnõ & koñjam (கொஞ்சம்) & 'some, little, few' \\
\hline kurre & *kuire & kūrai (கூரை) & 'roof' \\
\hline o:de & *o:de & ọdai (ஓடை) & 'canal' \\
\hline po:n & *pon & peṇ (பெண்) & 'bride' \\
\hline rete & *rette & irațtai (இரட்டை) & 'twins' \\
\hline
\end{tabular}

Table 8. Colloquial Tamil loans in Sri Lanka Malay (Paauw 2004).

For the sake of completeness, it should be added that Sri Lanka Malay also exhibits some lexical influence from Sinhala, although the role of the latter as a lexifier is more modest than that of Tamil. Some examples from Paauw (2004) are given in Table 9; the tentative Sinhala precursors are mine.

\begin{tabular}{|l|l|l|}
\hline Sri Lanka Malay & Sinhala & Meaning \\
\hline ko:ci & kōcci & 'train' \\
\hline maheteya & mahattayā & 'Sir' \\
\hline nari:ya & nariyā & 'fox' \\
\hline po:re & pōra & 'manure' \\
\hline pus & pus & 'mould on food' \\
\hline rastiyadu (ja:di) & rastiyādu & 'to roam without a purpose' \\
\hline (ru:ma) o:la & ōla & 'cadjan hut' \\
\hline siwura & siwura & 'robe' \\
\hline tape & tāppe & 'bund, retaining wall' \\
\hline te:ro & tera & 'Buddhist monk' \\
\hline
\end{tabular}

Table 9. Sinhala loans in Sri Lanka Malay (Paauw 2004). 


\section{LEXICAL TRACES OF MIXED LANGUAGES}

This section highlights a number of poorly described and quickly disappearing Malay varieties influenced by Tamil, whose documentation is typically restricted to small glossaries. The available information is therefore largely lexical. The aforementioned variety used by the Chitty, also known as Malaccan Creole Malay, has around 200 remaining speakers in Malacca, while an even smaller group have migrated to Singapore in the early twentieth century (Dhoraisingam 2006). Some brief notes on their language are given in Moorthy (1997). The most complete analysis of this Malay variety is a lexico-phonological description by Mohamed (2006). Phonologically as well as syntactically, Chitty Malay appears to be quite similar to Baba Malay. In all likelihood, both varieties developed out of a stabilized form of Bazaar Malay.

In terms of phonology, we find several more characteristics of pidginderived Malay varieties, including the monophthongization of / au/ to /o/ and / ai/ to /e/ and the deletion of / $\mathrm{h} /$. The glottal stop, however, is retained in Chitty Malay. As in Baba Malay, a word-final glottal stop - written as <k> - is added to a limited number of words (Mohamed 2006: 93):

(21) Addition of word-final glottal stop in Chitty Malay:

$\begin{array}{lll}\text { bawa } & >\text { bawak } & \text { 'to bring' } \\ \text { cari } & >\text { carik } & \text { 'to search' } \\ \text { garu } & >\text { garok } & \text { 'to scrape' } \\ \text { nasi } & >\text { nasik } & \text { 'boiled rice' }\end{array}$

Chitty Malay also exhibits the assimilation of consonant cluster / $\mathrm{mb} /$ to $/ \mathrm{m} /$ in intervocalic position. This phonological innovation is also attested, for instance, in Baba Malay, Kelantan Malay and subdialects in Kedah and Sarawak (Mohamed 2006: 92), but not among (other) pidgin-derived Malay varieties.

In terms of lexicon, Chitty Malay is predominantly Malay. Some Tamil vocabulary occurs in the domains of family members, religious terms, cultural items, traditional clothes, food, and wedding-related terms (Mohamed 2006: 124-127). A small selection of these loanwords is presented in Table 10.

\begin{tabular}{|l|l|l|}
\hline $\begin{array}{l}\text { Chitty Malay } \\
\text { (Malacca) }\end{array}$ & Tamil & Meaning \\
\hline aneng & ạnnan (அண் ன்) & 'elder brother' \\
\hline arjanai & arccañai (அர்ச்சனை) & 'a religious ritual' \\
\hline besti & vēṣti (வேஷ்டி) & 'white man's cloth' \\
\hline kolem & kōlam (சோலம்) & $\begin{array}{l}\text { 'ornamental figures drawn on floor } \\
\text { with rice flour' }\end{array}$ \\
\hline pandaram & paṇ̣āram (பண்டாரம்) & 'assistant temple priest' \\
\hline
\end{tabular}




\begin{tabular}{|l|l|l|}
\hline $\begin{array}{l}\text { Chitty Malay } \\
\text { (Malacca) }\end{array}$ & Tamil & Meaning \\
\hline parpu & paruppu (பருப்பு) & 'pigeon peas' \\
\hline patrige & pattirigai (பத்திரிகை) & 'invitation card for a wedding' \\
\hline sudem & sūḍan (சூடன்) & 'camphor' \\
\hline talpa & talaippā (தலைப்பா) & 'turban' \\
\hline
\end{tabular}

Table 10. Some Tamil loans in Malaccan Chitty Malay.

Upon comparing the short glossary of Singaporean Chitty Malay given in Dhoraisingam (2006: 94), we see some minor discrepancies in pronunciation (Table 11), possibly due to infrequent usage or dialectical differences.

\begin{tabular}{|c|c|c|}
\hline Chitty Malay (Singapore) & Tamil & Meaning \\
\hline aneng & ạ̣nạn (அண் ணன்) & 'elder brother' \\
\hline arshaneh & arccañai (அர்ச் சனை) & 'a religious ritual' \\
\hline kaboleh & kuvalai (குவளை) & ‘drinking vessel’ \\
\hline pandarom & pạ̣̣̄āram (பண் டாரமீ) & 'assistant temple priest' \\
\hline prasadom & pirāsādam (பிராசாதம்) & 'food offered in temple' \\
\hline təlpah & talaippā (தலைப் பா) & 'turban' \\
\hline
\end{tabular}

Table 11. Tamil loans in Singaporean Chitty Malay.

A comparable mixed variety must have existed in Penang. This commercial entrepôt, historically belonging to the Kedah Sultanate, was frequented by South Indian communities from pre-colonial times. Since its acquisition in 1786 by the East India Company, the British encouraged foreign settlement, including from India and China. In a description of this dialect as it was used in the early twentieth century, Hamilton (1922: 57) contends that Penang Malay "is really the Malay of Kedah altered slightly to suit the needs of a cosmopolitan town population with a large element of Southern Indians from the Madras Presidency". The author lists various lexical items, many of which borrowed from Tamil and Hindustani, that make this dialect stand out among other Peninsular Malay varieties. When I checked these words with Penang Malay speakers in 2014, many of them were only recognized by people older than 40 , who associated them with the speech of their parents and grand parents. Penang Malay has recently converged with a more mainstream type of colloquial Malay found, with minor regional differences, across West Malaysia. Table 12 lists the Penang Malay words given in Hamilton (1922) that go back to Tamil. 


\begin{tabular}{|l|l|l|}
\hline $\begin{array}{l}\text { Old Penang } \\
\text { Malay }\end{array}$ & Tamil & Meaning \\
\hline candi & caṇdi (சண்டி) & 'stubborn of a horse' \\
\hline macan & maccān̄ (மச் சான்) & 'the husband of an elder sister' \\
\hline maini & manni (மன்னி) & 'the wife of an elder brother' \\
\hline mambu & vēmbu (வேம் பு) & 'the neem tree' \\
\hline mami & māmi (மாமி) & 'aunt' \\
\hline mandom & mandam (மந் தம்) & 'worthless, a broken down horse' \\
\hline pərli & purali (புரளி) & 'to tease, to deceive' \\
\hline pili & pīli (பீலி) & 'a water tap' \\
\hline ponen & peṇnạn (பெண்ணன்) & 'impotent' \\
\hline poni & pōṇi (போணி) & 'a small, tin vessel' \\
\hline ponu & peṇ (பெண்) & 'a bride' \\
\hline sule & sūlai (குலை) & 'a rheumatic swelling in the joints' \\
\hline tairu & tayir (தயர்) & 'curds' \\
\hline
\end{tabular}

Table 12. Tamil loans in (old) Penang Malay.

In addition, some words in Penang Malay can be attributed to colloquial Malayalam, a language closely related to Tamil. These include potoras 'pride, arrogance' from patrās ( $\backsim(\circlearrowleft) \mathrm{m})$ ) and pokəri 'a profligate, a blackguard' from

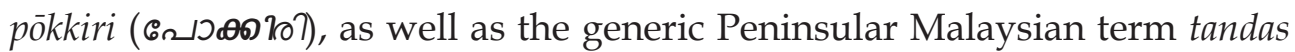
'toilet' from tandās (ளைวग $\breve{u}){ }^{29}$ I have looked at pre-modern Malayalam borrowings into Maritime Southeast Asia in another paper (Hoogervorst in press a), but this topic remains underexplored.

Studies on Malay language contact rarely take into account colloquial speech or dialects, neither of the donor nor the recipient language. We may mention in passing the neighbouring dialect of Kedah, which exhibits the loanwords kambi 'plain metal earring' (Tamil: kambi; கம்ப 'kind or earring') and kawar 'thief; trespasser' (Tamil: kavar; கவர் 'to steal') (Asmah 1966). A systematic study will almost certainly reveal more examples. On a related note, I would argue that lexicographic practices obscure the actual influence of Tamil on generic Malaysian Malay, as numerous loanwords known to and used by its speech community are omitted in most dictionaries. Table 13 lists some examples.

29 I am indebted to Abdur Rahoof Ottathingal and Mahmood Kooria for bringing this to my attention. 


\begin{tabular}{|l|l|l|}
\hline Malaysian Malay & Tamil & Meaning \\
\hline dipawali ( deepavali) & dīpāvaḷi (தீபாவளி) & 'name of a festival' \\
\hline kawadi ( kavadi) & kāvaḍi (காவடி) & $\begin{array}{l}\text { 'a decorated pole carried } \\
\text { on shoulders with } \\
\text { offerings' }\end{array}$ \\
\hline taipusam ( thaipusam) & taippūsam (தைப் பூசமீ) & 'name of a festival' \\
\hline tose & tōsai (தோசை) & 'kind of rice-cake' \\
\hline toti & tōț̣i (தோட்டி) & 'a menial servant' \\
\hline umapodi & ōmappoḍi (ஓமப்பொடி) & 'kind of confectionary' \\
\hline
\end{tabular}

Table 13. Tamil loans in Malaysian Malay.

In addition, several Malaysian slang words have escaped the attention of linguists. This is a largely unexplored field requiring knowledge of both Malay and Tamil slang. Elsewhere I call attention to the Malay slang word rendek'to be together with someone', which goes back to colloquial Tamil rendu (ரெண்டு) 'two' (Hoogervorst in press b). ${ }^{30}$ Other examples that I have collected during several brief periods of fieldwork in and around Kuala Lumpur are listed in Table 14.

\begin{tabular}{|c|c|c|}
\hline Malaysian slang & Tamil slang & Meaning \\
\hline aney & aṇṇē (அண்ணே) & 'employee of mamak restaurant' \\
\hline ауоуо & aiyyayō (ஐய் யயோ) & INTJ \\
\hline maca & maccā (மச்சா) & 'buddy' \\
\hline manjen & mañjañ ( மஞ் சன்) & 'Chinese man (derogatory)' \\
\hline nandrek & nañri (ந ன்றி) & ‘Thank you!' \\
\hline pondan & peṇ̦an (பெண்டன்) & 'effeminate man' \\
\hline porah $\sim$ podah & pōḍā (போடா) & 'Get lost!' \\
\hline pundek & punḍai (புண்டை) & 'cunt' \\
\hline tanggaci & tan்gaicci (தங் கைச்சி) & 'girl' \\
\hline yilek & illai (இல்லை) & 'absent' 32 \\
\hline
\end{tabular}

Table 14. Malaysian slang words borrowed from Tamil slang.

30 The word final $\langle\mathrm{u}>$ is pronounced as a high central rounded vowel $/ \mathfrak{u} /$ in spoken Tamil. The colloquial pronunciation of this form, hence, is / rend $\sharp$. Interestingly, the same word is attested in the gold traders' slang of Malang (Table 16).

31 Original meaning: 'elder brother'.

32 Original meaning: 'no'. 


\begin{tabular}{|c|c|c|}
\hline Kojak form & Tamil & Meaning \\
\hline aambille & āṇbillai (ஆண்பிள்ளை) & 'husband' \\
\hline kaliyaanam & kalyāṇam (கல்யாணம்) & 'marriage' \\
\hline koobdu & kūppiḍu (கூப்பிடு) & 'to invite' \\
\hline maliyu & malivu (மலிவு) & 'cheap' \\
\hline nombu & nōn̄bu (நோன்பு) & 'to fast' \\
\hline patche & paccai (பச் சை) & 'virgin'33 \\
\hline pille $\sim$ polle & piḷai (பள் ளை) & 'children' \\
\hline pombile & peṇbillaiai (பெண்பிள்ளை) & 'wife' \\
\hline salli & salli (சல்லி) & 'money' \\
\hline satte & sațtai (சட்டை) & 'shirt' \\
\hline soro & sōra (சோறு) & 'rice' \\
\hline thahpan & tahappañ (தகப் பன்) & 'father' \\
\hline vange & vāngu (வாங் கு) & 'to buy' \\
\hline
\end{tabular}

Table 15. Tamil loans used by the Kojak community in Semarang.

Indonesia exhibits a slightly different situation. With the exception of North Sumatra (Mani 1993a), Tamil communities were generally too small to remain independent and eventually assimilated into the mainstream. In Indonesia, the most common Malay term to denote Indian Muslims was Koja Kojah $\sim$ Khoja, from the aforementioned Khojō and ultimately from Persian Khhwāja (خو اجه) 'a man of distinction'. The word is first documented in the late fourteenth century in the Tanjung Tanah manuscript, which was written by a certain Kuja Ali (Mahdi 2015). Javanese exhibits the related word Koja 'merchant (usually Muslim Indian)'. Historically, several harbours on Java's north coast had a Pakojan; a quarter where the Koja resided. While the term Khojā normally implies a northwest Indian origin, the eponymous community in the north Javanese city of Semarang traces their ancestors to Tamil-speaking Marakkāyar, with a small minority of Māppila and Gujarati Khojā (Mani 1993b: 126). At one point, they may have spoken a mixed language akin to Chitty Malay. Mani (1993b: 126-127) briefly addresses the "secret" language of this mercantile community, which at the time of his research was only used by speakers older than 40 . Some examples are given in Table 15 above (spelling of the Kojak forms as in original).

Another Tamil-influenced in-group language has been documented in Malang. In the 1950s and 1960s, the gold trade in this East Javanese city was dominated by Indians. Even when local people took over in the 1970s, their cryptolect still consisted of Tamil words (Pujileksono and Kartono 2007: 23-24; Hoogervorst 2014: 114-115). Some examples are given in Table 16. 


\begin{tabular}{|l|l|l|}
\hline Malang slang & Tamil & Meaning \\
\hline ilek & illai (இல்லை) & 'not' \\
\hline ina & enña (என்ன) & 'what' \\
\hline pati & pattu (பத்து) & 'ten' \\
\hline pesi & pēsu (பேசு) & 'to chat, to lie' \\
\hline pocik & poci (பொசி) & 'inferior gold' \\
\hline renḍik & reṇḍu (ரெண்டு) & 'two' \\
\hline sarik & sāru (சாரு) & 'beautiful' \\
\hline tanggəm & tan்gam (தங்கம்) & 'gold' \\
\hline weleh & vilai (விலை) & 'price' \\
\hline werəm & vayiram (வயிரம்) & 'diamond' \\
\hline
\end{tabular}

Table 16. Tamil loans in Malang slang.

The opposite phenomenon has also been documented. In colonial times, the cryptolects of the Tamil-speaking Paraiyar community in Jaffna (Lewis 1890) and the merchants of the Coromandel Coast (Pandit 1894) have been identified as partly inspired by Malay or a closely related language (Kern 1894; Hoogervorst 2013: 17-18, 27-28). Unsurprisingly, multilingual traders would have communicated in a language they picked up far away to keep their transactions back home a secret.

\section{MALAYICIZED TAMIL?}

As the previous three sections have explored Malay varieties influenced by Tamil, this section discusses localized Tamil varieties of Maritime Southeast Asia. As has been discussed in Section 2, the historical practice among Indian merchants to marry into local, Malay-speaking families gave rise to a wealthy, influential generation of bilinguals. The linguistic competence of such hybrid communities, however, would typically decrease as they assimilated into the mainstream. In all likelihood, a stabilized, "Malayicized" variety of Tamil could only develop in recent times, with substantial numbers of women to ensure intergenerational transmission. Whether we can indeed speak of such a variety remains open for discussion. It may be pointed out that Tamil has been used as a medium of education and local literary works in Malaysia and Singapore since the independence of both nations (see Willford 2006: 45-52). While the phrase "Malaysian Tamil" occasionally surfaces in the literature (compare Renganathan 2009), it is rarely qualified. In general, scholarship on any aspect of Malaysian Tamil remains limited and poorly distributed (see, for example, Fernandez 2008; Karunakaran and Krishnan 2013). A monographlength description of colloquial Malaysian or Singaporean Tamil is still needed. 
The available information is at times contradictory. For example, Venugopal (1996: 5) contends that Malaysian Tamil is relatively Anglicized. He points towards the English educated background of most Malaysian Tamils and gives some examples of lexical influence from English in Malaysian Tamil literature (Venugopal 1996: 285-286). Conversely, Ramasamy and Moses (2004: 58-59) hold that Indian Tamil contains a comparatively larger proportion of English, implying that Malaysian Tamil has remained closer to its roots. The authors further state that there is little dialectical difference in Malaysia, as opposed to India (and Sri Lanka). In addition, they call attention to a number of common Malay loanwords in Malaysian Tamil, as listed in Table 17. The fact that many Tamil-speakers learned Bazaar Malay would have accounted for this situation. ${ }^{34}$

\begin{tabular}{|l|l|l|l|}
\hline Malaysian Tamil & Malay & Standard Tamil & Meaning \\
\hline a:tta:ppu & atap & kūrai (கூரை) & '(thatched) roof' \\
\hline campo:ru & campur & cēr (சேரீ) & 'to mix' \\
\hline kla:mbare & kəlambu & kosuvalai(கொசுவலை) & 'mosquito net' \\
\hline pasa:ru & pasar & candai (சந்கை) & 'market' \\
\hline saron & sarung & kaili (கைலி) & 'sarong' \\
\hline vakulu & bakul & kūdai (கூடை) & 'basket' \\
\hline
\end{tabular}

Table 17. Malay loans in Malaysian Tamil (Ramasamy and Moses 2004: 59).

In his treatise on Malaysian literature in Tamil, Venugopal (1996: 299) lists a number of words he considers to be characteristic of Tamil used in Malaysia. These include some Malay loanwords, such as itik 'duck', janji 'promise', kəpala 'head', lalang 'tall grass', lampu 'light', ringgit 'dollar', rokok 'cigarette', samsu 'illicit liquor', salosai 'solved', sanang 'easy', səpatu 'shoe' and tukang 'carpenter'. The Tamil spelling and pronunciation of these words are not given, which makes the examples of limited use for linguistic purposes. The author also calls attention to a number of neologisms specific to Malaysian Tamil, such as āyäkkotțagai (ஆயாக்கொட்டகை) 'child centre', kākkā kadai (காக்கா கடை) 'Indian Muslim shop' and pirattukkalam (பிரட்டுக்களம்) 'the place where workers give their names for attendance'. More examples of Malaysian Tamil vocabulary are given in a pioneering lexical study of the Tamil dialects in lower Perak (Subbiah 1966). Some instances of Malay loanwords in Lower Perak Tamil are listed in Table 18.

34 Venugopal (1996: 301) provides examples of code-mixing and code-switching between Tamil and colloquial Malay in Malaysian Tamil literature, but does not present any first-hand data. 


\begin{tabular}{|c|c|c|}
\hline Lower Perak Tamil & Malay & Meaning \\
\hline attāppu (அத்தாப்பு) & atap & 'roofing-thatch' \\
\hline $\begin{array}{l}\text { beṇḍān (பெண்டான் ) veṇụān } \\
\text { (வெண்டான்) }\end{array}$ & bəndang & 'irrigated paddy fields' \\
\hline īttai (ஈத்தை) & itik & 'a duck' \\
\hline kampam (கம்பம்) & kampung & 'a Malay settlement' \\
\hline kīlā (\& லா) & gila & 'mad' \\
\hline kirās (கி ராஸ்) & kəras & 'tight, stiff' \\
\hline kōsam (கோசம0) & kosong & 'empty' \\
\hline kurisu (குரிசு) & kurus & 'lean' \\
\hline lombam (லொம்பம்) & lombong & 'a tin mine' \\
\hline pārān் (பாராங்i ) & barang & 'goods, things' \\
\hline piñjam (பிஞ்சம்) & pinjam & 'a loan' \\
\hline sālā (சாலா) & salah & 'fault' \\
\hline sīlāppu (ஜோப்பு) & silap & 'a fault' \\
\hline tāngā (தாங்கா) & tangga & 'house steps' \\
\hline tonkān̄ (தொங்கான்) & tongkang & 'a large boat' \\
\hline vakkul (வக்குள்) & bakul & 'a basket' \\
\hline
\end{tabular}

Table 18. Malay loans in Lower Perak Tamil (Subbiah 1996).

Balasubramaniam (1994) offers another isolated contribution to the study of Malaysian Tamil. In his exploration of the language used by tea pluckers and factory workers in the tea estates of the Cameron Highlands, he calls attention to a number of loanwords and hybrid constructions (Table 19).

\begin{tabular}{|l|l|l|l|}
\hline $\begin{array}{l}\text { Cameron Highlands } \\
\text { Tamil }\end{array}$ & Meaning & $\begin{array}{l}\text { Malay } \\
\text { element }\end{array}$ & Meaning \\
\hline bońkusu kāmarā & $\begin{array}{l}\text { 'section where packing is } \\
\text { done' }\end{array}$ & bungkus & 'packet' \\
\hline campalac-cūra & 'wage slip, salary slip' & surat & 'letter' \\
\hline jāmānkoțtāy & 'latrine' & jamban & 'toilet' \\
\hline kāmarā & $\begin{array}{l}\text { 'room type structure; } \\
\text { section of factory' }\end{array}$ & kaməra & $\begin{array}{l}\text { 'chamber, } \\
\text { cabin' }\end{array}$ \\
\hline kappalā & $\begin{array}{l}\text { attendant in the estate } \\
\text { dispensary' }\end{array}$ & kəpala & 'head' \\
\hline
\end{tabular}




\begin{tabular}{|l|l|l|l|}
\hline $\begin{array}{l}\text { Cameron Highlands } \\
\text { Tamil }\end{array}$ & Meaning & $\begin{array}{l}\text { Malay } \\
\text { element }\end{array}$ & Meaning \\
\hline lampuk-kāsu & $\begin{array}{l}\text { 'light money (money } \\
\text { deducted from the } \\
\text { workers' pay)' }\end{array}$ & lampu & 'lamp, light' \\
\hline tițti & 'a day off' & cuti & $\begin{array}{l}\text { 'leave of } \\
\text { absence' }\end{array}$ \\
\hline tōmpukoțțāy & $\begin{array}{l}\text { 'shed for heating water in } \\
\text { large drums for bathing' }\end{array}$ & tong & 'drum' \\
\hline
\end{tabular}

Table 19. Loanwords and hybrid constructions in Cameron Highlands Tamil (Balasubramaniam 1994).

Unsurprisingly in the light of the strong connections of Southeast Asian Tamils to their ancestral land, some of these Malay loanwords gained currency back in India. Contemporary examples include kittā (கித்தா) 'rubber' (Malay: gətah) and sēvā (சேவா) 'to rent' (Malay: sewa). ${ }^{35}$ Elsewhere, I have called attention to other examples of Malay loanwords in Tamil (Hoogervorst 2013). The lexical items highlighted in the latter study were presumably transmitted before interethnic commerce in the Indian Ocean World had become a Europeandominated enterprise. A selection is given in Table 20.

\begin{tabular}{|l|l|l|}
\hline Tamil & Malay & Meaning \\
\hline jōngu (சோங்கு) & jung & 'sea-going ship' \\
\hline kaiyāppuḍai (கையாப்புடை) & kayu putih & 'cajuput tree' \\
\hline kajaṅgu (கசஙiகு) & kajang & $\begin{array}{l}\text { 'mat protection against the } \\
\text { rain' }\end{array}$ \\
\hline kākkattuvāñ (காக்கத்துவான்) & kakaktua & 'cockatoo' \\
\hline kambīr (கம்பீர்) & gambir & 'a plant used for betel chewing' \\
\hline kịisu (கிறிசு) & kəris & 'a kind of dagger' \\
\hline sagu (சகு) & sagu & 'sago' \\
\hline sāmbal (சம்பால்) & sambal & 'chili-based spicy sauce' \\
\hline sambān̄ (சம்பான்) & sampan & 'a type of boat' \\
\hline sappan்gi (சப்பங்கி) & səpang & 'a type of fragrant wood' \\
\hline tan்gān̄ (தங்கான்) & təngahan & 'half' \\
\hline
\end{tabular}

Table 20. Malay loans in Tamil (Hoogervorst 2013). 


\section{CONCLUSIONS}

In his treatise on Malaysian Tamil literature, Venugopal (1996: 285) contends that "[p]urity of language is not found in the writings of these novelists". Diglossia and the existence of high-status literary languages have made expressions of the above type almost commonplace in both South and Southeast Asia. Yet notions of language purity obstruct, rather than stimulate, in-depth linguistic research. Academic attention to the colloquial and dialectical registers of Malay and Tamil remains remarkably sparse, although the situation is gradually improving for Malay. The traditional focus on "high language" has left the vernacular dimensions of language contact across the Bay of Bengal largely underexplored, leading to an imbalanced understanding of the cultural history of this part of the world. Indeed, while artists, scholars and scribes feature prominently in South and Southeast Asian historiographies, merchants, middlemen and labourers remain poorly documented. That the latter groups were vital to the introduction of products and ideas across geographical and ethno-linguistic boundaries becomes clear - among many other things - from the lexical and grammatical influence of Tamil and Hokkien dialects on Malay contact varieties, including Sri Lanka Malay. The role of Indian communities in these networks deserves closer academic attention in the future.

If we are to understand the wide range of activities underpinning cultural and linguistic contact in the Bay of Bengal and elsewhere, we need to focus on non-standardized languages. I have mentioned in passing the influence of Malayalam on the Peninsular Malay varieties. This topic merits a more thorough analysis than has been possible here. The same holds true for specific Tamil dialects or sociolects, especially those belonging to mercantile groups (both Hindu and Muslim). Fieldwork-based grammatical descriptions of Shonam, Malaysian Tamil and Malay spoken by Tamils, too, are lacking to this day. Local scholarship in this area is often of great interest, but poor distribution leaves much of it neglected in wider academic circles. Meanwhile, there is no reason to believe that similar mixed languages did not exist before colonial times. Varieties spoken by the hybrid communities highlighted in this paper must have been common historically. The present overview has only been able to scratch the surface of the linguistic processes and phenomena emerging at the crossroads of Malay and Tamil.

Two major problems remain in advancing this area of study. Foremost, much of the scattered scholarship on language contact at the interface of Malay and Tamil is done in a linguistically haphazard way. For phonologically complex languages such as Tamil, either an IPA representation or consistent transliteration with diacritics are prerequisites for up-to-standard data presentation. If the phonology of the languages under research is disregarded, painstakingly collected data will lose much of their value to serious linguistic research. The second problem has to do with post-colonial paradigms in academia. With some notable exceptions, humanities scholars based in South and Southeast Asia tend to treat Indonesian, Malaysian, Indian and Sri Lankan (language) history as teleological narratives, without considering events taking 
place outside the present-day borders of the countries under research. Yet at the same time, a series of pivotal, transnational events left a deep impact on all regions involved. One prominent example is the emergence of the Malay printing press in Colombo and later in Singapore, which was spearheaded in both cities by culturally hybrid groups. More comparative work in the fields of historical linguistics, literature, manuscript studies, religion, and other disciplines is required to explore broader perspectives of language contact and etymology in some of the world's most diverse and exciting language ecologies.

$\begin{array}{ll}\text { ABBREVIATIONS USED } \\ 1 & \text { : first person } \\ 2 & \text { : second person } \\ 3 & \text { : third person } \\ \text { DEM } & \text { : demonstrative } \\ \text { GEN } & \text { : genitive } \\ \text { NEG } & \text { : negation } \\ \text { INTJ } & \text { : interjection } \\ \text { PART } & \text { : particle } \\ \text { PL } & \text { : plural } \\ \text { POS } & \text { : possessive } \\ \text { PST } & : \text { past } \\ \text { SG } & \text { : singular } \\ \text { SOV } & \text { : subject-object-verb }\end{array}$

\section{REFERENCES}

Adelaar, A.K. 1991. "Some notes on the origin of Sri Lanka Malay", in: Hein Steinhauer (ed.), Papers in Austronesian linguistics, pp. 23-37. Canberra: Australian National University.

Adelaar, A.K. 1996. "Malay in the Cocos (Keeling) Islands", in: Bernd Nothofer (ed.), Reconstruction, classification, description; Festschrift in Honor of Isidore Dyen, pp. 167-198. Hamburg: Abera Verlag.

Adelaar, A.K, 2005. "Structural diversity in the Malayic subgroup", in: Alexander K. Adelaar and Nikolaus P. Himmelmann (eds), The Austronesian languages of Asia and Madagascar, pp. 202-226. London/New York: Routledge.

Adelaar, A.K and D.J. Prentice. 1996. "Malay; Its history, role, and spread", in: S.A. Wurm, P. Mühlhausler, and D. Tryon (eds), Atlas of languages of intercultural communication in the Pacific, Asia, and the Americas, pp. 673-693. Berlin/New York: Mouton de Gruyter.

Aisyah, Siti. 2014. "Religious and commercial networks lexicalized; Interpreting a unique quadrilingual manuscript". [Paper, Conference "Sailing the waves of convergence; Cultural links and continuities across the Bay of Bengal", Leiden, 3 December.] 
'Ālim, Tayka Shu'ayb. 1993. Arabic, Arwi, and Persian in Sarandib and Tamil Nadu; A study of the contributions of Sri Lanka and Tamil Nadu to Arabic, Arwi, Persian, and Urdu languages, literature, and education. Madras: Imāmul 'Arūs Trust.

Aman, Norhaida; Viniti Vaish; Wendy Bohkorst-Heng; Aisha Jamaludeen; Durgadevi P.; Feng Ying Yi; Khoo Boon Suan; Mardiana Roslan; Pauline Appleyard; and Tan Teck Kiang. 2009. The sociolinguistic survey of Singapore 2006. Singapore: Centre for Research in Pedagogy and Practice, National Institute of Education.

Ansaldo, Umberto. 2008. "Sri Lanka Malay revisited; Genesis and classification”, in: K. David Harrison, David S. Rood, and Arienne Dwyer (eds), Lessons from documented endangered languages, pp. 13-42. Amsterdam / Philadelphia: John Benjamins.

Ansaldo, Umberto. 2014. "SLM is dead, long live Sri Lanka Malay; A review article of Nordhoff 2013", Journal of Language Contact 7: 381-391.

Ardika, I.W. and Peter Bellwood, 1991. "Sembiran; The beginnings of Indian contact with Bali", Antiquity 65(247): 221-232.

Asmah, binte Haji Omar. 1966. "The natural of Tamil loan words in Malay", Proceedings of the First International Conference of Tamil Studies, Kuala Lumpur. Vol. II, pp. 534-558. Kuala Lumpur: International Association of Tamil Research.

Balasubramaniam, P. 1994. "Occupational registers in selected tea estates", Journal of Tamil Studies 46: 39-54.

Bayly, Susan. 1989. Saints, Goddesses and Kings; Muslims and Christians in South Indian society 1700-1900. Cambridge: Cambridge University Press.

Bellina, Bérénice and Ian Glover. 2004. “The archaeology of early contact with India and the Mediterranean World, from the fourth century BC to the fourth century AD", in: Ian Glover and Peter Bellwood (eds), Southeast Asia; From prehistory to history, pp. 68-88. London/New York: Routledge Curzon.

Birch, E.W. 1969. "The vernacular press in the Straits”, Journal of the Malaysian Branch of the Royal Asiatic Society 41/1 (215): 192-195.

Christie, Jan Wisseman. 1999. "Asian sea trade between the tenth and thirteenth centuries and its impact on the states of Java and Bali", in: Himanshu Prabha Ray (ed.), Archaeology of seafaring; The Indian Ocean in the ancient period, pp. 221-270. Delhi: Pragati Publications.

Damais, L-C. 1964. “Études sino-indonésiennes. III. La transcription chinoise Ho-ling comme désignation de Java", Bulletin de l'École française d'ExtrêmeOrient 52(1): 93-141.

Daw, Khin Khin Aye. 2005. Bazaar Malay; History, grammar, and contact. Singapore: National University of Singapore.

Dhoraisingam, Samuel S. 2006. Peranakan Indians of Singapore and Melaka; Indian babas and nonyas - Chitty Melaka. Singapore: Institute of Southeast Asian Studies.

Feener, R. Michael and Terenjit Sevea (eds). 2009. Islamic connections; Muslim 
societies in South and Southeast Asia. Singapore: Institute of Southeast Asian Studies.

Fernandez, Robinson John Joseph. 2008. "Swear words used by male Indian undergraduates in daily conversation". MA thesis, University of Malaya.

Fujimoto, Helen. 1989. The South Indian Muslim community and the evolution of the Jawi Peranakan in Penang up to 1948. Tokyo: Tokyo Gaikokugo Daigaku.

Gan, Kok Siong. 1982. "Satu kajian mengenai Bahasa Melayu yang dipertuturkan oleh penutur Tamil". Bangi: Universiti Kebangsaan Malaysia. [Working paper.]

Gwee, William Thian Hock. 2006. A Baba Malay dictionary; The first comprehensive compendium of Straits Chinese terms and expressions. Tokyo: Tuttle Publishing.

Guillot, C. and Moh. Ali Fadillah. 2003. Histoire de Barus; Le Site de Lobu Tua. II: Etude Archéologique et Documents. Paris: Association Archipel. [Cahier d'Archipel 30.]

Guilmoto, Christophe Z. 1993. "The Tamil migration cycle, 1830-1950", Economic and Political Weekly 28/3-4: 111-120.

Hamilton, A.W. 1922. "Penang Malay", Journal of the Straits Branch of the Royal Asiatic Society 85: 67-96

Hassan, Abdullah. 1969. "Bahasa Melayu Pasar di Malaysia Barat", Dewan Bahasa 8(5): 207-218.

Hill, A.H. 1955. "The Hikayat Abdullah; An annotated translation", Journal of the Malayan Branch of the Royal Asiatic Society 28: 5-354.

Hoogervorst, Tom G. 2013, Southeast Asia in the ancient Indian Ocean World. Oxford: Archaeopress. [BAR International Series 2580.]

Hoogervorst, Tom G. 2014. "Youth culture and urban pride; The sociolinguistics of East Javanese slang", Wacana, Journal of the Humanities of Indonesia (Children and youth culture) 15/1: 104-131.

Hoogervorst, Tom G. in press a. "Detecting pre-modern lexical influence from South India in Maritime Southeast Asia", Archipel.

Hoogervorst, Tom G. in press b. "Malay youth language in West Malaysia", NUSA; Linguistic Studies in and around Indonesia 58.

Hussain, Mustapha. 2005. The memoirs of Mustapha Hussain; Malay nationalism before UMNO. Kuala Lumpur: Utusan Publications.

Hussainmiya, B.A.1990. Orang Rejimen; The Malays of the Ceylon Rifle Regiment. Bangi: University Kebangsaan Malaysia.

Hussainmiya, B.A. 2008. "Fusion of cultures; The Malays and Moors in Sri Lanka". [Paper, Second Annual Asian Cultural Studies Association Conference "Asian ways; Traditions and transitions", Bangkok, 5-6 August.]

Hussein, A. 2007. Sarandib; An ethnological study of the Muslims of Sri Lanka. Dehiwala: Asiff Hussein.

Jayasuriya, Shihan de Silva. 2002. "Sri Lankan Malay; A unique creole”, NUSA 50: 43-57.

Jones, Russell. 2007. Loan-words in Indonesian and Malay; Compiled by the Indonesian Etymological Project. Leiden: KITLV Press. 
Juynboll, H.H. 1899. “Eene episode uit het Oudindische Râmâyana vergeleken met de Javaansche en Maleische bewerkingen", Bijdragen tot de Taal-, Landen Volkenkunde van Nederlandsch-Indië 50(1): 59-66.

Kader, Mashudi. 1971. “Bahasa Melayu Pasar; Satu kajian pertembungan Bahasa Melayu Umum dengan Bahasa Tamil di Kuala Lumpur". MA thesis, University of Malaya, Kuala Lumpur.

Karashima, N. and Y. Subbarayalu. 2009. "Ancient and medieval Tamil and Sanskrit inscriptions relating to Southeast Asia and China", in: H. Kulke, K. Kesavapany, and V. Sakhuja (eds), Nagapattinam to Suvarnadwipa; Reflections on the Chola Naval Expeditions to Southeast Asia, pp. 271-291. Singapore: Institute of Southeast Asian Studies.

Karunakaran, K. and R. Krishnan. 2013. “Syntactico-semantic study of particles in Modern Malaysian Tamil", Language in India 13(5): 167-182.

Kern, Johan Hendrik Caspar. 1894. "Over de herkomst van eenige telwoorden in 't Bargoensch der Zuidindische kooplieden", in: Feestbundel van taal-, letter-, geschied-en aardrijkskundige bijdragen ter gelegenheid van zijn tachtigsten geboortedag aan Dr. P.J. Veth, oud-hoogleraar, door eenige vrienden en oud-leerlingen aangeboden, pp. 199-200. Leiden: Brill.

Kessler, Clive S. 1992. "Archaism and modernity; Contemporary Malay political culture", in: Joel S. Kahn and Francis Loh Kok Wah (eds), Fragmented vision; Culture and politics in contemporary Malaysia, pp. 133-157. Sydney: Allen and Unwin.

Khoo, Salma Nasution, 2014. The Chulia in Penang; Patronage and place-making around the Kapitan Kling Mosque 1786-1957. Penang: Areca Books.

Kob, Ajid Che. 1989. "Pengaruh dialek dalam pembelajaran Bahasa Indonesia Standard di kalangan pelajar-pelajar", in: Abdullah Hassan, Hasnah Ibrahim, and Mashudi Kader (eds), Kesalahan bahasa dalam Bahasa Malaysia, pp. 490-505. Kuala Lumpur: Dewan Bahasa dan Pustaka.

Krom, N.J. 1913. Oud-Javaansche oorkonden; Nagelaten transscripties van wijlen Dr. J.L.A. Brandes. Batavia: Albrecht; The Hague: M. Nijhoff. [Verhandelingen van het Bataviaasch Genootschap van Kunsten en Wetenschappen 60.]

Lewis, J.P. 1890. "Slang of Tamil castes", Indian Antiquary 19: 160.

Lim, Sonny. 1981. Baba Malay; The language of the "Straits-born" Chinese. Melbourne: Monash University.

Mahdi, Waruno. 2000. "Review of 'Sanskrit loan-words in Indonesian; An annotated check-list of words from Sanskrit in Indonesian and Traditional Malay, in: NUSA, Linguistic Studies of Indonesian and Other Languages in Indonesia 41, by J.G. de Casparis (1997, Jakarta: Badan Penyelenggara Seri NUSA, Universitas Katolik Indonesia Atma Jaya)“', Bijdragen tot de Taal-, Land-en Volkenkunde 156: 844-852.

Mahdi, Waruno. 2015. "Script and language of the Tanjung Tanah manuscript", in: Uli Kozok (ed.), The Tanjung Tanah codes of law, pp. 162-220. Singapore: ISEAS.

Mani, A. 1993a. "Indians in North Sumatra", in: K.S. Sandhu and A. Mani (eds), Indian communities in Southeast Asia, pp. 46-97. Singapore: ISEAS. 
Mani, A. 1993b. "Indians in Jakarta", in: K.S. Sandhu and A. Mani (eds), Indian communities in Southeast Asia, pp. 98-127. Singapore: ISEAS.

McPherson, Kenneth. 1990. "Chulias and Klings; Indigenous trade diasporas and European penetration of the Indian Ocean littoral", in: G. Borsa (ed.), Trade and politics in the Indian Ocean; Historical and contemporary perspectives, pp. 33-46. Delhi: Manohar.

Mohamed, Noriah. 2006. “Deskripsi leksiko-fonologi Bahasa Kreol Melayu Chitty Melaka”. Penang: Universiti Sains Malaysia. [Research report.]

Moorthy, Ravichandran. 1997. “Bahasa komuniti Chitty Melaka; Tinjauan sejarah, persoalan linguistik, dan pola umum", Dewan Bahasa 41(1): 40-65.

Muniandy, Rajantheran. 1995. Hikayat Seri Rama; Perbandingan versi Melayu, Sanskrit dan Tamil. Kuala Lumpur: Dewan Bahasa dan Pustaka.

Noor, Farish A. 2012. Islam on the move; The Tablighi Jama'at in Southeast Asia. Amsterdam: Amsterdam University Press.

Nordhoff, Sebastian. 2009. A grammar of Upcountry Sri Lanka Malay. Utrecht: LOT.

Nordhoff, Sebastian (ed.). 2013. The genesis of Sri Lanka Malay; A case of extreme language contact. Leiden/Boston: Brill.

Nuhman, M.E. 2007. Sri Lankan Muslims; Ethnic identity within cultural diversity. Colombo: International Centre for Ethnic Studies.

Oetomo, Dédé. 1987. The Chinese of Pasuruan; Their language and identity. Canberra: Department of Linguistics, Research School of Pacific Studies, Australian National University. [Pacific Linguistics D63.]

Onn, Farid M. 1989. "Masalah sebutan dalam Bahasa Malaysia; Yang ini, yang itu, atau yang mana?", in: Abdullah Hassan, Hasnah Ibrahim, and Mashudi Kader (eds), Kesalahan bahasa dalam Bahasa Malaysia, pp. 74-91. Kuala Lumpur: Dewan Bahasa dan Pustaka.

Paauw, Scott, H. 2004. "A historical analysis of the lexical sources of Sri Lanka Malay". MA thesis, York University.

Paauw, Scott H. 2008. The Malay contact varieties of eastern Indonesia; A typological comparison. Buffalo, NY: State University of New York.

Pakir, Anne Geok-In Sim. 1986. A linguistic investigation of Baba Malay. PhD thesis, University of Hawaii, Honolulu.

Pandit, Natesa Sastri. 1894. "Traders' slang in Southern India", The Indian Antiquary 23: 49-52.

Pearson, Michael, 2010. "Islamic trade, shipping, port-states and merchant communities in the Indian Ocean, seventh to sixteenth centuries", in: David O. Morgan and Anthony Reid (eds), The New Cambridge History of Islam. Vol. 3: The Eastern Islamic World, eleventh to eighteenth centuries, pp. 317-365. Cambridge: Cambridge University Press.

Perret, D. and H. Surachman (eds). 2009. Histoire de Barus-Sumatra. III: Regards sur une place marchande de l'océan Indien (XIIe-milieu du XVIIe s.). Paris: EFEO, Association Archipel. [Cahier d'Archipel 38.]

Pigeaud, G.Th. 1962. Java in the fourteenth century; A study in cultural history, The Nāgara-Kĕrtāgama by Rakawi Prapanca of Majapahit, 1365 A.D. IV. Commentaries and recapitulations. The Hague: Nijhoff. 
Pujileksono, Sugeng and Rinekso Kartono. 2007. Model pelestarian budaya lokal melalui Bahasa Walikan Malangan dalam menciptakan integrasi di Kota Malang. Malang: Universitas Muhammadiyah Malang.

Rafferty, Ellen. 1982. Discourse structures of the Chinese Indonesian of Malang. Jakarta: Atma Jaya University. [NUSA 12.]

Raghavan, R. 1977. "Ethno-racial marginality in West Malaysia; The case of the Peranakan Hindu Melaka or Malaccan Chitty community", Bijdragen tot de Taal-, Land-en Volkenkunde 133(4): 438-458.

Ramasamy, Krishnan and Balan Moses. 2004. "Tamil”, in: Asmah Haji Omar (ed.), Languages and literature, pp. 58-59. Singapore: Archipelago Press.

Renganathan, Sumathi. 2009. "Exploring the researcher-participant relationship in a multiethnic, multicultural and multilingual context through reflexivity", Qualitative Research Journal 9(2): 3-17.

Ricci, Ronit. 2011. Islam translated; Literature, conversion, and the Arabic cosmopolis of South and Southeast Asia. Chicago and London: University of Chicago.

Ricci, Ronit. 2013. "The world's first Malay newspaper", Indonesia and the Malay World 41(120): 168-182.

Ronkel, Ph.S. van. 1902. "Het Tamil-element in het Maleisch", Tijdschrift voor Indische Taal-, Land-en Volkenkunde 45: 97-119.

Ronkel, Ph.S. van. 1904. "Een Maleisch gezantschap naar het Tamilland", Bijdragen tot de Taal-, Land- en Volkenkunde van Nederlandsch-Indië 56: 311316.

Ronkel, Ph.S. van. 1918 "Drawidische volksnamen op Sumatra", Bijdragen tot de Taal-, Land-en Volkenkunde van Nederlandsch-Indië 74: 263-266.

Ronkel, Ph.S. van. 1919. “Aanteekeningen op een ouden Maleischen Ramajanatekst", Bijdragen tot de Taal-, Land-en Volkenkunde van Nederlandsch-Indië 75: 379-383.

Ronkel, Ph.S. van. 1922. "A Tamil Malay manuscript", Journal of the Straits Branch of the Royal Asiatic Society 85: 29-35.

Saldin, B.D.K. 1993. "Bahasa Melayu Sri Lanka”, Jurnal Dewan Bahasa 39(11): 997-1020.

Scherer, G.A. 1891. "Nog altoos het Atjeh-vraagstuk", Tijdschrift voor Nederlandsch Indië (new series) 20(1): 283-315, 321-356.

Schiffman, Harold F., 1999. A reference grammar of spoken Tamil. Cambridge: Cambridge University Press.

Skinner, C. 1982. Ahmad Rijaluddin's Hikayat Perintah Negeri Benggala. The Hague: Nijhoff.

Slomanson, Peter. 2011. "Dravidian features in the Sri Lankan Malay verb", in: Claire Lefebvre (ed.), Creoles, their substrates, and language typology, pp. 383-409. Amsterdam/Philadelphia: John Benjamins.

Snouck Hurgronje, C. 1893. De Atjèhers. Deel 1. Batavia: Landsdrukkerij; Leiden: E.J. Brill.

Subbiah, Rama. 1966. A lexical study of Tamil dialects in Lower Perak. Kuala Lumpur: University of Malaya.

Teo, Kok Seong. 2003. The peranakan Chinese of Kelantan; A study of the culture, 
language, and communication of an assimilated group in Malaysia. London: ASEAN Academic Press.

Tschacher, Torsten. 2001. Islam in Tamilnadu; Varia. Halle-Wittenberg: MartinLuther-Universität.

Tschacher, Torsten. 2009. “Circulating Islam; Understanding convergence and divergence in Islamic traditions of Ma 'bar and Nusantara", in: R. Michael Feener and Terenjit Sevea (eds), Islamic connections; Muslim societies in South and Southeast Asia, pp. 48-67. Singapore: Institute of Southeast Asian Studies.

Venugopal, Sababathy. 1996. Malaysian Tamil novels after independence. Kuala Lumpur: University of Malaya Press.

Voorhoeve, P. 1952. "Indonesische handschriften in de Universiteitsbibliotheek te Leiden", Bijdragen tot de Taal-, Land-en Volkenkunde 108(3): 209-219.

Wall, H. von de. 1877-97. Maleisch-Nederlandsch woordenboek. Edited by H.N. van der Tuuk. Batavia: Landsdrukkerij. 3 Vols and appendix.

Willford, Andrew C. 2006. Cage of freedom; Tamil identity and ethnic fetish in Malaysia. Ann Arbor, MI: University of Michigan.

Wolff, John U. and Soepomo Poedjosoedarmo. 1982. Communicative codes in Central Java. Ithaca, NY: Southeast Asia Program, Department of Asian Studies, Cornell University. 